\title{
Psychological Trauma: Experience from Iraq
}

\section{AbdulKareem AlObaidi}

Visiting Scholar at Institute of International Education (IIE), NY, USA

Iraq is a Middle East country, part of the Arab world. The region is known as Mesopotamia, "the land between the two rivers", Tigris and Euphrates. It has been of fundamental historical and political significance as the site of ancient civilizations for thousands of years. Iraq's history is fertile in great creativity and invention leading to human development. However, sadly, it has also become the center of attention in modern political and military conflicts. People in Iraq have experienced a continuing traumatic history during the last four decades. Wars, political and religious violence \& oppression, forced displacement and migration, human right abuses, unemployment, and poverty have scourged Iraqi society, creating major public mental health crises [1]. Because of such high levels of armed violence, millions of Iraqis, particularly young people, have been killed or injured [2,3]. More than 4 million Iraqis were forced to leave their homes, either internally displaced, or becoming refugees in neighboring countries [4]. High levels of poverty and educational and health systems failures have affected the wellbeing of Iraqis, especially children [5]. Children form half of Iraqi population of approximately 33 million [6]. The already fragile infrastructures were ruined by massive looting and civil disorder which happened immediately after the 2003 US-led invasion of Iraq. Iraqis continue to live in a climate of fear of violence, with associated disruptions to daily activities having adverse effects on their mental health.

All the above reasons support the belief that psychological trauma and disorders are common in the Iraqi population. Worldwide estimations suggest that $10 \%$ of people who experience traumatic events of armed and violent conflicts have serious mental health problems. Another $10 \%$ suffer a decline in their social functioning [7]. Systemic review on published studies of PTSD following disasters including manmade disasters demonstrated that the burden of PTSD among persons exposed to is substantial [8]. A meta-analysis of epidemiological surveys in conflict-affected areas indicated prevalence of 15\% for PSTD [9]. This is substantially higher than the average in general populations of $7 \cdot 6 \%$ (for any anxiety disorder, including PTSD) [10].

The precise burden of psychological trauma and its mental health consequences in Iraq has been difficult to establish. There is a paucity of standardized research data on the psychological wellbeing of Iraqis. WHO reported that only $2 \%$ of all health research in Iraq carried on during 2000-2005 addressed mental health issues [11]. The first major mental health survey in Iraq was conducted during 2006/7 [12], concurrently with the Iraq Family Health Survey 2006-7 [13]. The survey adopted 'Composite International Diagnostic Interviews'. It focused on detecting affective and anxiety disorders from 4,332 adult respondents. Life time prevalence for all mental disorders screened (Anxiety, Mood, Behavioral and Substance- related Disorders) was $18.8 \%$. The prevalence rates for Anxiety, Mood, Behavioral and Substance-related disorders were $13.8 \%, 7.5 \%, 1.8 \%$ and $0.9 \%$, respectively. Posttraumatic Stress Disorders (PTSD) was rated as part of Anxiety disorders with a prevalence of only $2.5 \%$. Life time exposure to traumatic events was estimated to be $56 \%$. Low access to mental health care was suggested by the survey (only 6\%). The limited mental health services in Iraq are due the shortage of resources for care. These include shortages of mental health professionals, poor training, and funding as well as governmental and community inattention and stigma being related issues [14]. The results of this survey have been complicated by population movement and the unsecure environment that found at the time of the survey. The results have been affected by exclusion of internally displaced and refugees, children and adolescents; it didn't collect information on other mental disorders like schizophrenia, somatisation, cognitive or personality disorders [15].

Much higher rate had reported in other published study among adult survivors of two suicide bombings in Karbala a city in middle of Iraq during 2007, the study suggested (43.4\%) had PTSD [16]. Major national surveys of child and adolescent mental health are lacking in Iraq. A number of published studies focus on child and adolescent mental health problems in Iraq especially those who were exposed to war and violence related trauma. The scope of these studies is limited and there is little systematic coverage of the topic in the literature [17] One of the main themes was the post-war impact of violence on the mental and psychological well-being of Iraqi children and adolescents.

In Mosul (a large city in the north of Iraq), a study suggested $37 \%$ of children have mental disorders, $10.5 \%$ having PTSD [18] In Baghdad, the site of other study, $47 \%$ of primary school children reported exposure to a major traumatic event, 14\% had PTSD [19]. Among a sample of displaced children living on the Iraqi-Turkish border in Kurdistan (North of Iraq) in the aftermath of 1991 Gulf war, $20 \%$ of these children reportedly symptoms of posttraumatic stress disorder (PTSD) [20]. Recent figures on the prevalence of PTSD came from a survey conducted during 2010 among male adolescents from secondary schools in Baghdad. It suggested $55 \%$ of the boys aged 13-19 years have experienced trauma; $17.1 \%$ have symptoms of PTSD [21]. Among a clinical sample of children in Baghdad, 22\% had diagnoses of anxiety disorders including $6.7 \%$ with signs and symptoms of posttraumatic disorder [22]. High rates of mental health problems and trauma exposure have been reported among Iraqi refugees throughout the world [23-26].

The state of continuous insecurity and high levels of violence in Iraq call for urgent responses to meet the mental health needs of people in Iraq. Mental health services in war and violence- affected areas should be integrated into a variety of public services. These need to take into account in strategies to address the underlying determinants of mental health; these include issues related to reconciliation and justice [15,27]. It has been recommended that a system of low-cost service delivery staffed by well-trained health professionals is required that focuses on child, family, school-based and community mental health [28]. Every opportunity for raising the issues of mental health needs to be exploited.

${ }^{*}$ Corresponding author: AbdulKareem AlObaidi, Visiting Scholar at Institute of International Education (IIE), NY, USA, E-mail: kareemobaidi@gmail.com

Received October 17, 2013; Accepted November 18, 2013; Published November 20, 2013

Citation: AlObaidi A (2013) Psychological Trauma: Experience from Iraq. J Trauma Treat S4: 005. doi:10.4172/2167-1222.S4-005

Copyright: (c) 2013 AlObaidi A. This is an open-access article distributed unde the terms of the Creative Commons Attribution License, which permits unrestricted use, distribution, and reproduction in any medium, provided the original author and source are credited. 
Training in primary care \& public health needs to include sensitivity to mental aspects of clinical presentations for example, in antenatal visits, routine physical health contacts (using the issue of opportunistic checking of blood pressures as a model). A well trained workforce of health professionals within the primary health setting is needed for early-intervention services. Comprehensive, culturally sensitive mental health system based in the existing local infrastructure should be developed by local professionals and evaluated for the effectiveness of their outcomes.

\section{Reference}

1. Sharma S, Piachaud J (2011) Iraq and mental health policy: a post invasion analysis. Intervention 9: 332-344.

2. Hicks MH, Dardagan H, Guerrero Serdan G, Bagnall PM, Sloboda JA, et al. (2011) Violent deaths of Iraqi civilians, 2003-2008: analysis by perpetrator, weapon, time, and location. PLoS Med 8: e1000415.

3. Hicks MH, Dardagan H, Bagnall PM, Spagat M, Sloboda JA (2011) Casualties in civilians and coalition soldiers from suicide bombings in Iraq, 2003-10: a descriptive study. Lancet 378: 906-914.

4. Refugees International (2008) Uprooted and unstable: meeting urgent humanitarian needs in Iraq.

5. Al-Obaidi AK (2011) Iraq: Children and adolescents' mental health under continuous turmoil. International Psychiatry 8: 5-6.

6. Central Organization for Statistics (2011) Annual abstract of statistics 20102011.

7. Rossler W, Salize HJ, van Os J, Riecher-Rossler A (2005) Size of burden of schizophrenia and psychotic disorders. Eur Neuropsychopharmacol 15: 399-409.

8. Neria Y, Nandi A, Galea S (2008) Post-traumatic stress disorder following disasters: a systematic review. Psychol Med 38: 467-480.

9. Steel Z, Chey T, Silove D, Marnane C, Bryant RA, et al. (2009) Association of torture and other potentially traumatic events with mental health outcomes among populations exposed to mass conflict and displacement: a systematic review and meta-analysis. JAMA 302: 537-549.

10. Demyttenaere K, Bruffaerts R, Posada-Villa J, Gasquet I, Kovess V, et al. (2004) Prevalence, severity, and unmet need for treatment of mental disorders in the World Health Organization World Mental Health Surveys. JAMA 291: 2581-2590.

11. WHO Iraqi MoH (2006) WHO-AIMS Report on Mental Health System in Iraq. Iraqi Ministry of Health, Baghdad, Iraq; WHO.

12. Alhasnawi S, Sadik S, Rasheed M, Baban A, Al-Alak MM, et al. (2009) The prevalence and correlates of DSM-IV disorders in the Iraq Mental Health Survey (IMHS). World Psychiatry 8: 97-109.
13. WHO (2007) Iraq Family Health Survey 2006-2007.

14. Welch K, Abed R (2009) Current status of psychiatric inpatient services in Sulaimania and Erbil, Kurdistan regional government, Iraq. Heartland Alliance.

15. Medact (2012) Mental health policy in Iraq since 2003: a post- invasion analysis. London: Medact.

16. Abbas MJ, Al Haidary AF, Alghanimy S (2013) Prevalence of post-traumatic stress disorder among the survivors of two suicide bombings in Iraq International Psychiatry 10: 92-94.

17. AlObaidi AK, Corcoran T, Scarth L (2013) Psychosocial Research with Children in Iraq- Current Health Practice and Policy in a Context of Armed Conflict. International Psychiatry 10: 72-74.

18. Al-Jawadi AA, Abdul-Rhman S (2007) Prevalence of childhood and early adolescence mental disorders among children attending primary health care centers in Mosul, Iraq: a cross-sectional study. BMC Public Health 7: 274.

19. Razokhi AH, Taha IK, Taib NI, Sadik S, Al Gasseer N (2006) Mental health of Iraqi children. Lancet 368: 838-839.

20. Ahmad A, Mohamed HT, Ameen NM (1998) A 26-month follow-up of posttraumatic stress symptoms in children after the mass-escape tragedy in Iraqi Kurdistan. Nord J Psychiatry 52: 357-366.

21. Lafta R, AlObaidi AK, Aziz ZS (2013) Posttraumatic stress disorder among male students in secondary schools in Baghdad. Journal of Traumatic Stress (Submission).

22. AlObaidi AK, Scarth L, Dwivedi KN (2010) Mental disorder in children attending a child psychiatric clinic at the General Pediatric Hospital in Baghdad. Journal for International Mental Health Promotion 12: 24-30.

23. Al-Obaidi AK, Attalah SF (2009) Iraqi Refugees in Egypt: an exploration of their mental health and psychosocial status. Intervention 7: 145-151.

24. Norredam M, Garcia-Lopez A, Keiding N, Krasnik A (2009) Risk of mental disorders in refugees and native Danes: a register-based retrospective cohort study.

25. Laban CJ, Gernaat HB, Komproe IH, Schreuders BA, De Jong JT (2004) Impact of a long asylum procedure on the prevalence of psychiatric disorders in Iraqi asylum seekers in The Netherlands. J Nerv Ment Dis 192: 843-851.

26. Jamil H, Nassar-McMillan SC, Lambert RG (2007) Immigration and attendant psychological sequelae: a comparison of three waves of Iraqi immigrants. Am J Orthopsychiatry 77: 199-205.

27. IASC (2007) IASC Guidelines on Mental Health and Psychosocial Support in Emergency Settings. Inter-Agency Standing Committee.

28. Tol WA, Barbui C, Galappatti A, Silove D, Betancourt TS, et al. (2011) Mental health and psychosocial support in humanitarian settings: linking practice and research. Lancet 378: 1581-1591.
This article was originally published in a special issue, Post Traumatic Stress Disorders handled by Editor(s). Dr. Agius M, University of Cambridge, UK 